\title{
DISCURSIVE ANALYSIS OF AUTO/BIOGRAPHICAL NARRATIVES ON THE BASIS OF PRISON CAMP LITERATURE
}

\author{
by Joanna Bielecka-Prus
}

Biographical narratives are an integral part of the human life: we relate our stories, tell ourselves about ourselves, and others about others. By virtue of being so common, they have become an area of interest in many academic disciplines, with each field providing researchers with distinct analytical tools. As the interest in narratives increased, social sciences saw the emergence of the "narrative turn," and, subsequently, the "linguistic-textualist turn," which appeared in the 1980s (Wengraf, Chamberlayne \& Bornat, 2002). Biographical narrative has been investigated by such disciplines as literary criticism, history, sociology, philosophy, anthropology, ethnography, culture studies, and gender studies (Rak, 2005). Despite sharing a common area of interest, researchers' use of analytic tools from fields other than their own remains very limited. The resulting hermeticism may be rooted in the lack of understanding of other perspectives, inability to employ analytic terms in research, or fear of losing one's own research identity. By overcoming these concerns and expanding the analytical framework, it may be possible to discover new insights into the research subject.

\section{The Discursive Turn in Narrative Studies}

Following the anthropological distinction between life as experience (what the individuals experience, what meaning they give to the events, what the accompanying emotions are) and life as a narrative (a text embedded in 
a context, addressed to a recipient, the rules governing its creation) (Bruner, 1984, p. 7), it can be noted that each approach involves different methodological implications. Whereas the former emphasizes the ways in which the narrator interprets the world and the accompanying emotional states (a phenomenological, naturalistic approach) (cf. Denzin, 1989), the latter entails a 'cold,' post-positivist analytical perspective. It is the approach where "a storied narrative is the linguistic form that preserves the complexity of human action with its interrelationship of temporal sequence, human motivation, chance happenings, and changing interpersonal and environmental contexts" (Polkinghorne, 2005/1995, p. 7). The crisis of representation undermined the previously held assumptions of realism, which concerned the authenticity of the related events (Sermijn, Devlieger, \& Loots, 2008), as well as the thesis about the story's coherence and linearity. The narrative outlines thematic areas which can be rather loosely interlinked and ordered in a series of non-linear events. It is a "rhizomatic story" that grows in a number of different directions without a clearly marked beginning or end.

Post-structuralism has expanded the narrative analysis by introducing a 'hidden power' dimension, which produces "speaking selves" (e.g. Foucault, 1972). Communicative competence of the speaker is closely linked to the socially established systems validating individual's actions. Not all narratives are equally powerful, as their strength depends on the "felicity conditions" (Searle, 1969, p. 60) and establishing credibility through linguistic as well as visual means, for instance by illustrating a biography with photos (cf. Howarth, 2000).

On the other hand, constructivism has drawn attention to the fact that a narrative is not only a linguistic attempt at representing past events, but also a speech act in Searle's understanding: communication creates social reality. Narratives constitute the reality in which the individual lives, his/her relationship with the world, and his/her identity (Bruner, 1991). A story about one's self is never a story about the real ' $\mathrm{I}$ '; rather, it is an "attempt at reconstruction," as noted the renowned Polish sociologist Jadwiga Staniszkis (2008), who used the phrase in her autobiographical memoir. The narrator's self is fragmented, unstable, developing, and changing as the story advances. Furthermore, constructivism regards narratives as joint activities of the speaker and the listener, where their mutual interaction shapes both what is told and how it is described. According to this approach, a narrative is not a product, but an "embodied social practice" (Sclater, 2003, p. 622), a story embedded in two contexts: on the one hand, it recounts events that took place in a certain social space and social time; on the other, telling a story is in itself an act situated in a particular place, time, and within given social relations. 


\section{Autobiography as a Narrative}

As a special type of narrative, autobiography is regarded as a form of literary expression, a personal document whose author tries to recreate his/her life. More precisely, it is a "retrospective prose narrative written by a real person concerning his own existence, where the focus is his individual life, in particular the story of his personality" (Lejeune, 1989, p. 4). In this type of texts the author is identified with the narrator (Tutak, 2003). Autobiographies differ from journals and diaries in that entries are not made on a daily basis, but rather with a delay, creating a time perspective. By doing so, the author is able to select and arrange the events into a coherent whole. In terms of literary genres, what makes it different from biography is greater emphasis on shaping the identity or revealing the agent (Rak, 2005). Autobiography is a communicative act through which the author tries to convince the reader that their report is true, their memory fresh, and that he/ she is capable of self-reflection, of accurately interpreting his/ her own life, and of being sincere (Mathien \& Wright, 2006).

On the other hand, rather than being an objective account of events, an autobiography is an active process of remembering. It resembles a portfolio of images from the past, often unordered, incomplete, with numerous gaps (cf. Gudmundsdóttir, 2003). While some events are brought to the fore, other provide a background, and other still, deemed unimportant, are altogether removed from the story.

If we assume that narrative is a form of investing events, objects, and actions with a meaning through a text, autobiography becomes a way of endowing with sense one's own life embedded in a social context. Thus, the story told is not merely a story about the self, but also about communities, groups, and people related to the narrator through an individual interpretation of events as well as via the collective memory (Polkinghorne, 2005/1995). Just like the biographical memory, the collective memory is selective and ideologized (Kaźmierska, 2008); it is also a story of other community's members, those whose voice is unheard, on whose behalf the author speaks (Denzin, 2001).

Autobiography is more than an account of events: it can take the form of a thorough self-analysis taking into consideration given ethical standards, as well as the form of self-defense against a possible attack by contesters (Mathien \& Wright, 2006). Immersed in a moral order, it is a history of a certain career, a trajectory of social roles, a story of fall and rebirth (Coffey \& Atkinson, 1996).

Similarly to other narratives, autobiographies can be investigated from a linguistic perspective, in which case what matters is how the 
autobiographical text is constructed, what cultural resources it employs, what linguistic resources are used to create meaning, and finally-what rhetorical strategies the author uses to convince the reader of the authenticity of the description.

\section{Discourse Analysis}

Biographical narratives can be regarded as a resource as well as a primary subject of research. The latter, following the constructivist paradigm, focuses on analyzing the ways of creating meaning, showing how something is told, and not only what the text is about (Silverman, 2011). Language is not a mirror reflecting the world, but an active factor organizing the reality within discourse practices (Potter \& Wetherell, 1987). As a result, some researchers question the coding procedure used most commonly in quantitative studies, which imposes a scheme external to the narrative. The alternative involves a multi-layered model (e.g. Mello, 2002) or a multifocal zoom model (Pamphilon, 1999), which distinguishes the following levels of analysis:

- the macro-zoom: collective dimensions of biography, discursive practices, dominant discourse, historical context;

- the meso-zoom: individual dimension of biography, discursive strategies, discourse absent from narrative;

- the micro-zoom: emotions expressed in a narrative with verbal and non-verbal means;

- the interactional-zoom: interaction between the narrator and the researcher, the sender and the recipient, as well as researcher's emotional responses to narrator's statements.

In accordance with the research schema, discourse analysis becomes the central analytic procedure, allowing for a reflection on the constructive role of language. Discourse stands for "all forms of spoken interaction, formal and informal, and written texts of all kinds" (Potter \& Wetherell, 1987, p. 7). It creates a system of meanings centered around a theme, and is realized in the form of a text created by the sender with a real or potential recipient in mind. Discourse enters into relationships with elements of the reality beyond it (social structures, social practices, agents, power, ideology) as well as with other discourses (cf. Foucault, 1972; van Dijk, 1997).

Discourse analysis "refers to the process of analysing signifying practices as discursive forms" (Howarth, 2000, p. 10). It focuses on studying linguistic means of expression: choices on the lexical, syntactic, and semantic levels, rules governing texts' creation, interpenetration of genres, 
intertextuality, and relations between the linguistic and non-linguistic contexts (social, historical, political, cultural) of the analyzed utterances. Notwithstanding the differences among analytic approaches developed as part of the discourse analysis, one can outline general assumptions concerning the relationship between the social and the linguistic phenomena:

- discourse constitutes the social world, and not only represents it;

- there are no 'true' representations, only better validated, since reality is polymorphic;

- discourse is a form of social action that influences individual and collective modes of thinking and acting, social relations, and individual's identity;

- there are social rules for creating, communicating, and interpreting discourse (discursive practices);

- discourse becomes institutionalized and is in that scope linked to social practices.

Discourse analysis assumes that one event can be told using various linguistic resources, and it is the narrator who chooses particular means of expression from the repertory of language and potential meanings in order to create his/her own representation of what happened (Halliday, 1978). The choice of linguistic means is contingent on a number of factors: writer's communicative competence, intentions, assumed recipient, communication context, and discursive practices accepted in a given community. Since narrative analysis can be centered around many aspects of language, their choice depends on the research problem and the type of the investigated text. However, the following issues seem to be of particular interest:

- the context: references to other texts (intertextuality) as well as embedding in a social context;

- the syntactic level: structure of the content, relationships between its segments, active/passive voice, subject's position, way of building complex sentences, coherence, focalization (perspective from which the narrative is presented);

- the lexical level: choice of words, their emotional value, associated ideologies, courtesies, naming and attribution strategies, hyperboles intensifying the story, epithets, personification, animation;

- the semantic level: thematic organization (primary and secondary themes), semantic macrostructures, common and assumed knowledge;

- the rhetorical structure level, including repetitions, similes, metaphors, metonymies, irony (van Dijk, 1998). 
Some researchers have observed that discourse analysis proves to be particularly useful in the identity and self-presentation studies. Analyzed with a discourse perspective in mind, a biographical narrative is a complex text containing multiple voices, often incompatible with one another. The analysis involves a survey of the categorization process applied to the roles of oneself and others, of the creation of oppositions, such as 'us-them,' through the use of personal and reflexive pronouns marking agency, of demonstratives which position the speaker in space (here/there/somewhere/those and so on), at the same time indicating social distance, and of possessive pronouns which link individuals with objects (Meinhof \& Galasinski, 2000). What is also studied is positioning, or social and emotional attitude of the individual toward others. Unlike the role, positioning is a dynamic relation which can be analyzed on two levels: that of a relationship between the protagonists of the story, and that of a relationship between the sender and the recipient (cf. Bamberg, 1997). The associations can be divided into the following types: intimacy, where a relationship develops between the narrator and the recipient; intensity, where the narrator's feelings about the described objects and events are expressed; and finally evaluation, where the narrator reveals his/her positive or negative attitude. The listed aspects of analysis should not be regarded as an exhaustive set, as the analytical tools used by researchers are dependent on the research problem and the investigated data.

\section{Example of Discourse Analysis: Prison Camp Autobiographies}

To demonstrate how to employ the most important terms provided by discourse analysis, I will discuss examples of two texts written by different authors, whose biographies, though different, have a particularly distressing experience in common: a stay in Soviet gulags, which became the central theme of the autobiographies. The first narrative was penned by Gustaw Herling-Grudziński (1919-2000), who describes his story as an exile in the Yertsevo camp, near Arkhangelsk, in Inny świat (A World Apart). ${ }^{1}$ The second autobiography, entitled Journey into the Whirlwind (1995 [1967]), ${ }^{2}$

1 The first English edition of Herling-Grudziński's book, translated from Polish, came out in 1951 as A World Apart and was published by William Heinmann Limited. Quotations in the article are drawn from this translation.

2 The English (1995) and Polish (2010) translations differ from the Russian original (1990). In the English version some passages were omitted, and the translator chose not to use a number of phrases from the camp language. In the analyzed excerpt, the Polish subchapter title was altered (Russian: Run for your life, Polish and English: Salvation 
was written by Eugenia Solomonovna Ginzburg (1904 or 1906-1977), who had been exiled to the Kolyma camp

Owing to the multitude of themes mentioned in the memoirs, I will focus on the passages describing the work of cutting down the taiga. Called "general work," it was one of the toughest, most grueling forms of forced labor, with time turning into a symbol of the exile: "But the father of all is our Russian forest with its genuinely golden tree trunks (gold is mined from them). And the oldest of all the kinds of work in the Archipelago is logging. [...] During the war years (on war rations) the camp inmates called three weeks at logging 'dry execution,'" explained emphatically Aleksandr Solzhenitsyn (1973, p. 199). Anne Applebaum (2003) observed that work was the function of the camps, while prisoners received full food rations only if they fulfilled the production norms, which under the given conditions proved exorbitant. Prisoners had to be useful; their suffering and subsequent death were merely a side effect, unintended and regarded by the authorities with indifference. Felling of the forests is described in the memoirs of both Herling-Grudziński and Ginzburg.

However, before commencing an in-depth analysis of the selected passages, I will briefly discuss the social and historical context in which both autobiographies are embedded. Ginzburg was arrested in 1937, at the beginning of the Great Purge, and released in 1949. Herling-Grudziński, an active member of the Polish underground resistance movement, was arrested in 1940 by the NKVD ${ }^{3}$ during a failed attempt to escape to Lithuania. He was released after a hunger strike protest aimed at forcing the camp authorities to respect the 1942 amnesty following the Sikorski-Majski agreement. Both Herling-Grudziński and Ginzburg came from Jewish families, wrote politically-charged articles before the arrests, and were sentenced as political prisoners: the author of $A$ World Apart was given 5 years for attempting to "fight against the Soviet Union" (Herling-Grudzinski, 1951, p. 3), and Ginzburg received a 10-year sentence for "terrorist activity." Recollections of their stays in the prison camps were written down with a certain time perspective (7 years in the case of Herling-Grudziński, 10 years in the case of Ginzburg) and eventually came out in the West. Whereas Herling-Grudziński worked on his book while living in exile in London between $1949-50$ (i.e. before the death of Joseph Stalin), Ginzburg's

from heaven). The article is based largely on the English translation, sometimes also referring to the Russian one.

3 Narodnyy Komissariat Vnutrennikh Del (NKVD) is a large and complex police force, whose objective was tracking down and removing the assumed or real political opponents as well as maintaining control over the forced labor camps. NKVD is responsible for mass arrests, deportations, and executions of civilians. 
autobiography was written after the dictator's death, yet still-in spite of the post-Stalinist era surge of criticism-it stood no chance of being officially published. The manuscript (so called samizdat) was circled around until 1967, when it finally came out in Italy. Apart from certain similarities, there are also important differences separating the two biographies. Herling-Grudziński was Polish. He became actively involved in the life of pro-independence organizations of a socialist, but not pro-Russian, provenance. After the release he was a soldier in Anders' army, settled in Western Europe, worked for Radio Free Europe, and never moved back to Poland for good. On the other hand, Ginzburg was Russian. Having been a very active communist before her arrest, she was rehabilitated in 1955. After being released from the camp she moved to Moscow, where she worked as a journalist. She never left the Soviet Union.

Turning to the analysis of the narrative structure, one can note that both autobiographical stories begin with the arrest, which is followed by a description of the stay in prison, transport to the place of exile, time at the camp, and close with an epilogue of the protagonists regaining freedom. Ginzburg was often transferred between different camps in Kolyma as a result of the peculiar operating mode of the 'Gulag machine,' which moved human resources from one place to another. Herling-Grudziński stayed only in one camp. It can be therefore said that the account in Journey into the Whirlwind provides a broader context of the events in terms of temporal and spatial dimensions, also owing to diversified camp experiences.

In my analysis, I focus on the "meso-zoom" level, as described by Barbara Pamphilon (1999), taking into account the structure and style of the narratives as well as the singled out themes of place, people, and work. The analysis will address the following research problems: 1 . What significance is attributed to the described place? 2. How are the relations between people described, how are the naming and attribution strategies implemented? and 3. What is the importance attached to work understood as a characteristic of the daily camp reality?

\section{Text Structure and Positioning of the Author}

The theme I would like to analyze was highlighted by the author of $A$ World Apart in the chapter entitled Work (pp. 32-55); in Ginzburg's work, it covers several thematically related chapters: Elgen is the Yakut word for "dead," Free felling, Salvation from heaven (Ginzburg, 1994, pp. 395-416).

Ginzburg's narrative begins with her arrival in April 1940 in the female camp in Elgen, yet another place of work she was 'assigned to' through an 
anonymous administrative decision. What follows are the details concerning a part of the camp situated in the taiga, and an account of the meeting with a doctor who helped her find a better job 'under the roof.' The events are presented in the chronological order which is disrupted only once, when a song sung by a female prisoner brings back memories of the family home (p. 399). A few smaller sequences can be distinguished within the passage: arrival in the taiga, work, appearance of the evil foreman, struggle for survival, escape from death ("Once again, I had given death the slip" (p. 416)).

The investigated passage in Herling-Grudziński's work begins with a description of waking up in the morning, subsequently followed by an account of eating a meal, leaving for work, and coming back in the evening to the "zone" (the area overlooked by camp guards). The structure of the chapter is reminiscent of Aleksandr Solzhenitsyn's One Day in the Life of Ivan Denisovich. The events are presented chronologically, although sometimes the narrative is interwoven with author's contemplations of the camp life, or even philosophical reflections on the universal problems of mankind (such as freedom, destiny, loneliness).

As far as intertextuality is concerned, only Ginzburg's memoirs include direct references to other texts, which assume the form of literary associations. For instance, Jack London's White Fang is recalled in the context of the endless winter in Kolyma (pp. 395-396). In addition, the text contains allusions to works by Alexander Sergeyevich Pushkin (cf. p. 220, $222,255,292,295,320$ ) and Sasha Chorny (p. 266); there are also fragments of lullabies and prison songs. ${ }^{4}$ Furthermore, Journey into the Whirlwind presents voices of other people-female prisoners, supervisors. They take the form of a dramatic dialogue or monologue, which adds to the authenticity of the narrative. Internal focalization is prevalent throughout the text: the reader learns about the events predominantly from the author's point of view and through her feelings. There are, however, instances of external focalization, which is used when the narrator recounts the events she witnessed, but was not directly involved in. Internal focalization makes the description emotionally charged, which causes the sender and the recipient to become deeply involved in the story. Importantly, verbs are used in the present tense.

As a rule, Herling-Grudziński prefers external focalization. The narrative style is low-key, with the author's preference for reflections on the fate

4 The Russian original (1990) and the Polish translation (2010) recall also: proverbs („gość w dom-Bóg w dom," literally: "a guest in the house is God in the house"), a quote from Nikolai Vasilievich Gogol's Dead Souls, and excerpts from a poem by Marina Ivanovna Tsvetaeva. 
of all prisoners-which are absent from Ginzburg's work (e.g. "not one of them can ever know with any certainty when his sentence will come to an end" (p. 32)), complemented by exemplifications of camp life observations. In this case, authenticity is achieved through stressing personal experience ("I remember an old railwayman from Kiev" (p. 33)) and detailed descriptions. Activities performed by prisoners (getting up, having their first meal) as well as procedures related to calculating working norms and food distribution are described in a meticulous manner reminding one of the academic style (e.g. "by a quarter to six" (p. 34), "about three quarters of all prisoners" (p. 34)). The verbs are most frequently used in the past tense, while the way of capturing the events resembles reports of the anthropologists who investigated 'other worlds' only to stress in their accounts they did not belong to 'that' reality. Herling-Grudziński's text does not include any dialogues or references to texts beyond the prison camp discourse.

What is shared by both autobiographies is the inclusion of everyday prisoner vocabulary in authors' repertoires (e.g. "zone," "vokhra," "czunie," "toufta"), which further adds to the authenticity of the message, at the same time enhancing the narrator's authority.

\section{The Place}

Elgen, where Ginzburg was sent off, was an atrocious, frightening place: "the thing we dreaded had come upon us-transportation to Elgen, which had hung over us like a sword of Damocles" (p. 395). Elgen was considered a certain death sentence, which is conveyed on a number of occasions through utterances such as "Elgen is the Yakut word for 'dead" (p. 397), or "in summer there was haymaking on rough ground, if we lived to see it" (p. 400). Just like the author supposes, the place may stand not only for the end of her life, but also for the end of the human world, the end of civilization. The conjured image is monochromatic, with the dominating colors of white and grey. Descriptions of landscapes, observed while traveling from one place to another, have an aesthetic value, yet at the same time reveal the dreadful side of inanimate nature along with its dormant destructive power: "It was the fourth of April, but there was still a fortydegree frost and stiff breeze. The only sign of the approach of spring was the blinding splendour of the pure snow and the iridescent play of the sun's rays upon I, from which we could not tear our eyes. Alas, we did not yet know that the word 'blinding' was literally true: the fairytale beauty was treacherous"... (p. 396); used in this context, the "blinding splendour" metaphor can be understood literally as referring to eye 
inflammation prisoners often suffered from ("the word 'blinding' was literally true [...] the reflection of ultra-violet rays from the snow did indeed make people blind" (p. 396)). In the boundless space, the only clearcut, man-made points are those linked with the "zone" and its attributes: barbed wire, guard towers, gates, barracks, and a demarcated area for infants. Although squalid, the barrack, with its warm stove, boiler with hot water, smoke, and bread, becomes a 'homestead' providing a sense of security. It stands in stark contrast to the post in the depths of the taiga, a 'hen hut' with knotty bunks and a cell where the prisoner is deprived of the heat source and lair. Nevertheless, nature also turns out to be the source of salvation, which the author mentions writing about berries, the source of essential minerals for the prisoners suffering from avitaminosis: "Their taste was indescribable, like that of on old wine-and not to be compared with ordinary cranberries: its sweetness heady flavor were those of victory over suffering and winter. What a discovery... I ate the first two clusters all by myself; only on finding a third one did I remember my fellow creatures and call excitedly to Galya: 'Throw away your ax and come here. I've found «berries of golden wine».' With this quotation from Severyanin I described my treasure trove. From then on we went into the forest not in despair but in hope" (p. 412). The civilization/nature dualism is broken down: both lead to destruction, yet at the same time offer salvation.

Herling-Grudziński's description of the natural environment was minimized, leaving mere sketches of such items as snow, forest, stars, and the moon. However, the prisoners interpreted the immutable landscape and the "unchanging laws of nature" (p. 38) as a confirmation that living involved the ability to exist-in-the-world. The dominant characteristic of the narrative are-absent in Ginzburg's text-descriptions of objects: clothes, food, everyday items.

\section{The People}

In both analyzed narratives, the authors employ the strategies of 'naming' and 'attribution,' which make it possible to categorize the social world they situate themselves in. However, the texts differ between themselves with regard to the accepted mode of describing the social roles and relations.

Recalling her arrival in Elgen, Ginzburg speaks in the first person plural, using the verbs to report both actions (e.g. "we all fell silent" (p. 395), "we were getting farther and farther away" (p. 396)) and feelings ("We did indeed seem to have reached the back of beyond" (p. 395)). The 'we' 
constructed through such linguistic means gives prominence to the communal nature of women's fates, who came to the camp as novices sentenced for political reasons. While first-person narrative is a rhetorical strategy adding credibility to Ginzburg's story, by employing the plural, the author speaks on behalf of a group which is made up of the survivors and those who died in the camps. In addition, third-person narrative is used when describing the story or actions of a particular person, either known or watched by the narrator (e.g. "she skewered," "she roasted," "she's sweeping"), as well as other people the author tries to distance herself from (for instance when relating stories of wet nurses, criminal prisoners, or peasant women).

When it comes to outlining a general image of prisoners, the author often uses the strategy of 'dehumanization,' comparing her own group to "sheep [transported] to the slaughter" (p. 395). Other women become in Ginzburg's eyes "the muffled sexless figures" (p. 400). Although the author still considers herself a woman, she has a premonition she would be soon stripped of her sex, degraded and dehumanized, turning into a mere accessory to working tools. Possessive pronouns in the analyzed passage are fairly infrequent and usually refer to work ("our place of work" (p. 404)), clothing ("our own clothes" (p. 206)), and food ("our starvation $\operatorname{diet}^{\prime \prime}$ (p. 408)). Despite the fact that these three dimensions (work, clothing, food) are fundamental to and uniting all "zehks," ${ }^{5}$ the author distinguishes two groups from the 'amorphous' crowd: the decent people who help others, and the demoralized. The division is further multiplied by the institutional categorization, whose two main criteria are prison sentences and roles (political prisoners: counter-revolutionaries, Trotskyists and ordinary criminals, prostitutes, recidivists). Among the people evaluated positively are the team leader-a hard-working and generous peasant woman, and the 'real' doctor, who acts in accordance with medical ethics. As can be seen, the performed functions do not necessarily imply a negative moral evaluation. There are also groups of which the author is deeply contemptuous. They include, among others, common criminals, who, described as "strange," "offensive," and "ruthless," "thought nothing of stealing other people's footwear, pushing us away from the stove, or grabbing a sharper saw" (p. 406). Another group of people presented in a negative or mocking way are those who were assigned functions in the camp. The initial narrative sequences make no mention of the camp guards, except for the synecdoche "white, quilted sheepskin coats" (p.397),

5 Zehk or Z/K (abbreviated from the Russian zaklyuchennyj): prisoner in a camp (cf. Galler \& Marquess, 1972). 
which implies a better life situation in spite of (or maybe by virtue of) being uneducated, as proven by the books they read: "It was an elementary school textbook" (p. 416). The text also mentions other representatives of the camp regime, such as the health care administrator who decided if a female prisoner could be transported into the taiga instead of walking on her own. Still, the motivation behind such behavior was not entirely clear, as it could have been prompted by the fear of exceeding the set mortality threshold for "zehks" (p. 402). This may lead to the conclusion that norms were established not only in reference to work or food, but also death. Furthermore, one of the protagonists of Journey into the Whirlwind, foreman Kostik, inspected rows of prisoners "like a commander before a battle" ( $p$. 403), seeking a victim he would harass sexually. Ginzburg comments on the miserable and off-putting appearance of the women, trying to reconstruct his way of thinking: "perhaps they had been women once, but they weren't much to look at now, just walking skeletons-a real travesty" (p. 403). Another negative character is the second foreman, "the brute," who strictly adheres to the rules that impose excessively demanding working norms and is more than keen on resorting to detention. His appearance and the introduction of a new deadly order nearly cost the author her life. The process of 'reaching the shore' (dokhodyaga), ${ }^{6}$ which is a metaphor for a gradual death, forces the narrator to face the situation she has feared: she renounces herself. "This is not me!" (Ginzburg, 1990, p. 266) voiced as an exclamation is the last shout of a dying person who is struggling to stay alive. Thus, undoubtedly, the social world in Journey into the Whirlwind is closely linked with the moral order where Good clashes with Evil.

In terms of the description of relations between the prisoners and the camp administrators, the strategies of 'activization' and 'passivization' play a crucial role. The entities that make decisions regarding the prisoners' lives have been 'hidden' in sentences using the passive verb forms and the indeterminate 'they' ("we were taken out there on tractor-drawn trailers" (p. 402), "Several times a day they counted and recounted us, drew up lists and copied them out" (p. 328)). By employing this sentence structure, prisoners' actions are devoid of any intentionality; they are like objects moved around on the conveyor belt, like subjects surrendering to the power of authority. Besides, authority is assigned both to undefined decision-making groups (the omission strategy) and to fate, which ultimately brings salvation, proving that Good exists (cf. chapter Salvation from heaven).

6 Last-legger (legger from the Russian dokhodyaga, or 'reaching the shore,' 'goner'): a person extremely exhausted physically by hunger and hard labour. 
Contrarily to Ginzburg, Herling-Grudziński rarely uses the first-person narration. It is usually employed when describing the porters' brigade to which the author belongs. When talking about other protagonists, he most often uses the third-person narration, resorting to such terms as "prisoners" (see p. 32, 35, 37) and "slaves" (p. 37). Unlike in Journey into the Whirlwind, his categorization is not dependent on a set of moral criteria accepted a priori, but stems directly from the rules governing the camp life. Thus, bearing in mind the working norms and assigned food rations, the reader learns about "stakhanovites" (p. 37), whose daily work output exceeded $100 \%$ of the accepted norm, about prisoners who fulfilled the daily norm, and about "last-leggers." The second criterion for division is the type of the work carried out and the functions performed by the individuals in the camp. No clear distinction between the 'good' and 'bad' people exists; the worlds of prisoners and administrators are interwoven to the extent allowing for a "degree of friendliness" (p. 38) and the consent for "toufta" (pp. 40-41), which nevertheless does not protect this peculiar community from atomization ("There was in all this something inhuman, mercilessly breaking the only natural bond between prisoners-their solidarity in the face of their persecutors" (p. 37)); when struggling for life, each prisoner turned into a cog in the machine.

\section{The Work}

In Ginzburg's text, the hardships and suffering of the working women are pushed into the background; their pain is mentioned only sporadically. The author focuses mainly on presenting the struggle of women intellectuals, unaccustomed to hard physical labor, who were assigned the task of felling and sawing trees. For Ginzburg and her companions in misery the observed peasants, who met the assigned norms, turned into unattainable role models. The working day began with a painful awakening and a sensation of crippling hunger-consequences of failing to fulfill the norms. In her memoirs, the author demonstrates how making jokes about their clothing improved the mood, while the sense of humor proved they still "were human" (p. 408).

Descriptions of work in A World Apart are filled with details explaining the operation of biopower in the camp. It presents the division of labor, procedures for marching out and returning with brigades, complex system of committing "toufta," and calculating the fulfilled norms. The use of language filled with technical specifications, numerous nominalizations (e.g. "admissions of the porters' brigade" (p. 42), "the percentage figures were then passed to the supply office" (p. 43)), and 'hiding' the 
decision-making entities by employing the passive voice, as well as aggregation and/or omission all have direct bearing on the message: the description details the operations of a machine that puts living people "through the forest" (p . 41), at the same time picturing the impersonality of evil and its pointlessness.

\section{Conclusions}

By analyzing fragments of the prison camp discourse, it has been possible to demonstrate that in spite of functioning under similar conditions, the authors of autobiographies use different linguistic means to create distinct representations of their experiences. The texts differ in terms of the level of expressiveness. Ginzburg's work is more intimate, written from a personal perspective; her feelings and moral judgments are strongly emphasized. The narration in A World Apart is more objective, which makes it similar to a traditional fieldwork description. The two strategies correspond to distinct ways of adding credibility to the story: in one case the reader encounters captivating personal confessions, in the other-a distant description of the situation. What were the reasons for their use? Perhaps the answer lies in the differences between each author's camp experiences and the roles they played, including those related to their gender. The analysis of the writing styles in the autobiographies indicates considerable discrepancies between narratives constructed by women and men. Women are more interested in interpersonal relations and describe themselves as socially and emotionally involved. Conversely, men seem to be more autonomous, presenting themselves as independent and focused on achieving their own goals (Fivush \& Buckner, 2003). Furthermore, it is possible that in both discussed cases some other factors proved crucial, such as the authors' nationalities or their political background. Ginzburg was at the same time the victim and the creator of the system, which could explain why her emotional involvement in the events was significantly more intense than that of Herling-Grudziński, who was thrown into a foreign world he had been tied to neither historically nor politically. Moreover, it cannot be ruled out that the relatively short time spent in the camp-as compared to Ginzburg-meant that the author of A World Apart did not have to 'put down his roots.' 


\section{References}

Applebaum, A. (2003). Gulag: A History. London: Penguin Press.

Bamberg, M. (1997). Narrative Development: Six Approaches. Mahwah, NJ: Lawrence Erlbaum Associates.

Bruner, E.M. (1984). The Opening Up of Anthropology. In E.M. Bruner (Ed.), Text, Play and Story: The Construction and Reconstruction of Self and Society (pp. 1-16). Washington: American Ethnological Society.

Bruner, J. (1991). The Narrative Construction of Reality. Critical Inquiry, 18, 1-21.

Coffey, A., \& Atkinson, P. (1996). Making Sense of Qualitative Data: Complementary Research Strategy. Thousand Oaks - London - New Delhi: Sage.

Denzin, N.K. (2001). Interpretive Interactionism. London: Sage.

Denzin, N.K. (1989). Interpretive Biography. Newbury Park: Sage.

van Dijk, T.A. (1998). Ideology: A Multidisciplinary Approach. London: Sage.

van Dijk, T.A. (Ed.). (1997). Discourse as Structure and Process. London - Thousand Oaks - New Delhi: Sage.

Fivush, R., \& Buckner, J. (2003). Constructing Gender and Identity through Autobiographical Narratives. In R. Fivush \& C.A. Haden (Eds.), Autobiographical Memory and the Construction of a Narrative Self: Developmental and Cultural Perspectives (pp. 149-167). Hillsdale: Lawrence Erlbaum Associates.

Foucault, M. (1972). The Archeology of Knowledge and the Discourse on Language. (A.M. Sheridan Smith, Trans.). New York: Pantheon Books.

Galler, M., \& Marquess, H.E. (1972). Soviet Prison Camp Speech: A Survivor's Glossary. Madison: University of Wisconsin Press.

Ginzburg, E.S. (2010). Stroma ściana. (A. Mandalian, Trans.). Warszawa: Czytelnik.

Ginzburg, E.S. (1995 [1967]). Journey into the Whirlwind. (P. Stevenson \& M. Hayward, Trans.). Orlando: Harcourt Brace Jovanovich.

Ginzburg, E.S. (1990). Krutoj maršrut: Hronika vremen kul'ta ličnosti. Moskwa: Sovetskij Pisatel.'

Gudmundsdóttir, G. (2003). Borderlines: Autobiography and Fiction in Postmodern Life Writing. Amsterdam - New York: Rodopi B.V.

Halliday, M.A.K. (1978). Language as Social Semiotic: The Social Interpretation of Language and Meaning. London: Edward Arnold. 
Herling-Grudziński, G. (1951 [1953]). A World Apart. (J. Marek, Trans.). London: William Heinmann Limited.

Howarth, D. (2000). Discourse. Buckingham, UK: Open University Press.

Kaźmierska, K. (2008). Biografia i pamieć: Na przyktadzie pokoleniowego doświadczenia ocalonych z zagłady. Kraków: Zakład Wydawniczy Nomos.

Lejeune, P. (1989). On Autobiography. (P.J. Eakin, Ed.; K. Leary, Trans.). Series: Theory and History of Literature Series, Vol. 52. Minneapolis: University of Minnesota Press.

Mathien, T., \& Wright, D.G. (Eds.). (2006). Autobiography as Philosophy: Philosophical Uses of Self-presentation. London: Routledge.

Meinhof, U., \& Galasinski, D. (2000). East-West German Border Photography, Memory, and the Construction of Identities on the Former. Discourse Studies, 2, 323-353.

Mello, R.A. (2002). Collocation Analysis: A Method for Conceptualizing and Understanding Narrative Data. Qualitative Research, 2, 231-243.

Pamphilon, B. (1999). The Zoom Model: A Dynamic Framework for the Analysis of Life Histories. Qualitative Inquiry, 5, 393-410.

Polkinghorne, D.E. (2005/1995). Narrative Configuration in Qualitative Analysis. In J. Amos Hatch \& R. Wisniewski (Eds.), Life history and Narrative (pp. 5-23). Series: Qualitative Studies, Vol. 1. London - New York: Falmer Press.

Potter, J., \& Wetherell, M. (1987). Discourse and Social Psychology: Beyond Attitudes and Behaviour. London - Thousand Oaks - New Delhi: Sage.

Rak, J. (2005). Introduction-Widening the Field: Auto/biography Theory and Criticism in Canada. In J. Rak (Ed.), Auto/biography in Canada: Critical Directions (pp. 1-30). Waterloo: Wilfred Laurier University Press.

Sclater, D.S. (2003). The Arts and Narrative Research-Art as Inquiry: An Epilogue. Qualitative Inquiry, 9, 621-624.

Searle, J. (1969). Speech Acts: An Essay in the Philosophy of Language. Cambridge: Cambridge University Press.

Sermijn, J., Devlieger, P., \& Loots, G. (2008). The Narrative Construction of the Self: Selfhood as a Rhizomatic Story. Qualitative Inquiry, 14, 632-650.

Silverman, D. (2011). Interpreting Qualitative Data. Los Angeles - London - New Delhi - Singapore - Washington: Sage. 
Solzhenitsyn, I.A. (1973). The Gulag Archipelago, Vol. 2. (T.P. Whitney, Trans.). New York - San Francisco - London: Evanston.

Staniszkis, J. (2008). Ja: Próba rekonstrukcji. Warszawa: Prószyński i S-ka.

Tutak, K. (2003). Leksykalne nieczasownikowe wykładniki modalności epistemicznej w autobiografiach. Kraków: Księgarnia Akademicka.

Wengraf, T., Chamberlayne, P., \& Bornat, J. (2002). A Biographical Turn in the Social Sciences? A British-European View. Cultural Studies $\Leftrightarrow=>$ Critical Methodologies, 2, 245-269. 